\title{
Making ecosystem-based management operational: integrated monitoring in Norway
}

\author{
Maaike Knol
}

Correspondence: maaike.knol@uit.no Norwegian College of Fishery Science, University of Tromsø, 9037 Tromsø, Norway

\section{Introduction}

There is an increasing pressure on the world's seas and oceans. This is a consequence of the growing number and intensity of marine activities, such as fishing, shipping, tourism, mining, oil and gas extraction, and the development of renewable energy projects. In addition, there is a growing awareness of external factors such as pollution and climate change with their ecological and environmental consequences on the marine areas. These developments demand integrated forms of management at various levels (van Tatenhove 2011). The objects of marine governance are thus growing increasingly complex, and there is a widespread call for, and experimentation with, new marine governance instruments.

In line with this, the last decade has shown a trend towards ecosystem-based management (EBM) of marine areas (Browman and Stergiou 2004; Crowder and Norse 2008; Day et al. 2008; Curtin and Prellezo 2010; Österblom et al. 2010). EBM recognizes that the value of the whole ecosystem is greater than the sum of its parts and emphasizes that management systems should start from an understanding of ecosystems as complex, adaptive systems (Levin 1998; Gaichas 2008). One of the main objectives of EBM is to find ways to maintain the structure, function and productivity of the ecosystem in a

(C) 2013 Knol; licensee Springer. This is an Open Access article distributed under the terms of the Creative Commons Attribution License (http://creativecommons.org/licenses/by/2.0), which permits unrestricted use, distribution, and reproduction in any medium, provided the original work is properly cited. 
situation with increased human pressures. This implies that the state of the ecosystem or ecological quality - needs to be followed, which in turn requires measurement. For this reason, many countries and regions have existing and ongoing monitoring programs. These programs often look into single aspects of ecological quality and do not provide a comprehensive picture of ecological quality. EBM calls for the integration of existing practices with the objective of achieving a better overview of the state of an ecosystem. The development of integrated monitoring frameworks is becoming one of the central building blocks of ecosystem-based management (Day 2008; Douvere and Ehler 2011; Katsanevakis et al. 2011).

The establishment of integrated monitoring frameworks is a way to measure and follow ecological quality. But in order to measure quality there needs to be a reference framework. What is normal, and what are the critical limits of ecosystem functioning? What is the total load of effects that the environment can sustain? This paper describes the development of an integrated monitoring framework for the Barents Sea-Lofoten area in Norway. Expanding petroleum activity in this area has worked as a catalyst for the development and introduction of the first integrated, ecosystem-based management plan in Norway (Knol 2010a). The Barents Sea-Lofoten area is largely situated within the circumpolar area and is therefore considered to be extra sensitive to environmental change. This paper focuses on pollution monitoring in particular. This is a very current topic given the expected increase in oil and gas activities in a still relatively clean marine environment.

This work is based on an empirical investigation that has been part of a larger project that followed the developments towards, and the construction of, instruments for integrated, ecosystem-based management in the Barents Sea-Lofoten area (Knol 2010a). In-depth interviews were carried out between 2007-2010 with central persons in scientific and management institutions in Norway, which provided insight into the ways in which knowledge is used in the construction of ecosystem governance instrumentation. The management plan was implemented in 2006 (Ministry of the Environment 2006) and a revision was presented in 2011 (Ministry of the Environment 2011). Background reports and assessments produced for the plan and its revision were also studied.

What follows is a case study about the co-construction of governance instrumentation, in which scientific practices play a key part. The next section introduces a theoretical perspective placed within Science and Technology Studies (STS) and promotes the analytical relevance of studying the practices through which science, politics and nature are produced together in a context of marine governance. Then, the case study is introduced through a brief description of the turn towards integrated monitoring and EBM. The subsequent sections describe the co-construction of a monitoring framework for the Barents Sea-Lofoten area in Norway throughout various phases. The paper finishes with a discussion of key challenges that were faced in the design of this framework, which to a certain extent are still to overcome. This provides insight into the central issues that scientists and policy-makers meet when they design instruments, programs and practices to make EBM operational.

\section{Marine ecosystem governance in the making}

The implementation of ecosystem-based management is often studied from the perspective of its principles, guided by research questions that seek answers about the extent to 
which actual measures are able to live up to stated objectives. Such objectives are often formulated in general, and sometimes contradictory terms. They reflect ideal situations that produce social, economic and ecological sustainability at the same time. Such analyses are only to a small extent constructive and do not account for the fact that EBM is an ongoing process. In order to understand EBM as a performative practice with different possible outcomes, it is more productive to study marine ecosystem governance in the making through a focus on practices and the co-production of governance instruments at the science-policy interface (Knol 2010a). Here, the mobilization and enrolment of actors and information plays a key role.

The focus on instrumentation draws attention to the mechanisms of rule in changing modes of governance (Kassim and Le Galès 2010). This concept of instrumentation refers to "the set of problems posed by the choice and use of instruments (techniques, methods of operation, devices) that allow government policy to be made material and operational" (Lascoumes and Le Galès 2007). In environmental and marine governance, scientific or epistemic practices are key to the co-construction of instruments. Since the choice of instruments signifies the choices of policy, an analysis of the construction of governance instrumentation provides insight into the choices, assumptions, and effects of governance (Lascoumes and Le Galès 2007).

A study of instruments in the making enables the researcher to take a look at EBM as an ongoing process of co-production, that is, to explore "how knowledge-making is incorporated into practices of state-making, or of governance more broadly, and, in reverse, how practices of governance influence the making and use of knowledge" (Jasanoff 2004). The making of governance instruments takes place in processes that are increasingly entangled in knowledge-producing (or epistemic) practices. The focus on science as a practice, rather than as a product or result, is important in understanding the developments in marine governance. It sheds light on the fact that governance is an effect of actor's practices, which could have turned out differently if other choices were made. Understanding knowledge as an effect and an implication of situated practices is central to this type of analysis (Wehling 2006).

In line with other studies, this paper aims to show how nature is constructed in processes of co-production and how this, in turn, feeds into governance (Asdal 2003; Asdal 2008). This implies that there is no such thing as a pre-existing nature out there that is interesting for a sociological analysis of environmental or ecosystem governance. In Latour's words, Nature as such does not exist, but different natures - in plural - are constructed through scientific practices (Latour 2004). As Rouse argued, "knowledge is embedded in our research practices rather than being fully abstractable in representational theories" (Rouse 1987: 24; in Wehling 2006). What is most important in this paper is that nature, or the ecosystem, does not exist as something that is unambiguously given. It is our challenge to show how nature is constructed through processes of classification and categorization and how these practices feed into governance.

It is through these practices of classifying and categorizing that the contours of an ecosystem comes into existence; an object that is otherwise difficult to grasp. Practices of categorizing involves simplifications based on actor's choices about what is relevant, and this shows, again, that the actual construction could have turned out differently at different times, and in different places. Classifying and categorizing involve a wide variety of possible choices. The outcomes of these processes can stabilize into becoming 
the "boundary infrastructures" upon which governance is built. They link organizations and social worlds with multiple purposes and deal with regimes and networks of boundary objects (Bowker and Star 1999; Clarke and Star 2008). Such boundary infrastructures for marine governance can be mappings, or a framework of indicators, normal levels, and critical limits of different aspects of ecosystem functioning, as this paper describes. The stabilization of boundary infrastructures solidifies the choices made during the process of categorizing and classifying, and reinforces governance practices. They are the objectification of the performative practices that are taking place in processes of co-production. Boundary infrastructures can however remain "sites of intense controversy and competition for the power to define them" (Clarke and Star 2008: 121).

\section{From single-issue concerns to comprehensive management}

Monitoring of the oceans has developed from dealing with single-issue concerns such as the development of a specific fish stock, to becoming an instrument that is developed to making larger ecosystems readable and measurable. The history of monitoring of marine areas started with the International Council for the Exploration of the Sea (ICES) ${ }^{1}$ in the early $20^{\text {th }}$ century (McIntyre 1995). ICES' work was directed at research on fisheries. Over the years there was an increasing focus on how natural environmental factors influence the productivity of fish stocks.

Monitoring programs that are aimed at tackling marine pollution have a more recent history. They were developed in the period between the world wars, when there was a growing concern of the discharges of oil as part of the normal operations of shipping activity. In the decades thereafter, new threats for the oceans were perceived, such as the testing of nuclear weapons and the increasing use of pesticides (McIntyre 1995). The current concern of pollution in marine areas refers to the existence of metals, dioxins, synthetic organic compounds, radioactive waste, and plastics, among others. Sources of pollution are shipping, petroleum activities, fisheries, coastal industrial activity, but also long-range transboundary pollution where pollutants are transported through rivers and through the atmosphere.

The 1990s saw a growing concern over marine pollution. In 1990, during an interministerial conference in The Hague, ministers from various countries decided that countries should develop a methodology for the settlement of ecological quality objectives (see Ducrotoy and Elliott 1997). This can be seen as a major starting point and background for the development of integrated monitoring systems to follow marine ecological quality. During the $5^{\text {th }}$ North Sea Conference in Bergen in 2002 it was decided that ecosystem-based management had to be introduced for the North Sea. At this meeting the ministers also committed to the proposals for ecological quality objectives, which were compiled by ICES and OSPAR ${ }^{2}$. A set of ten ecological quality objectives were adopted for a pilot project in the North Sea (see von Quillfeldt and Dommasnes 2005: 11). The work on the establishment of ecological quality objectives and the selection of indicators for the Barents Sea builds upon this work carried out within OSPAR.

In large parts of the world's ocean areas, monitoring is in a similar way developing from being concerned with single issues to covering larger ecosystems and their environmental status and trends. It is becoming a central element in the development of approaches for 
ecosystem based management and marine spatial planning (Katsanevakis et al. 2011). The monitoring of pollution is becoming a key part in these holistic monitoring approaches.

\section{Making ecological quality readable and measurable}

Monitoring is meant to follow ecological quality. In the management plan for the Barents Sea-Lofoten area in Norway, ecological quality is defined as "an expression of the state of the ecosystem, taking into account the physical, biological and chemical conditions, including effects of anthropogenic pressures" (Ministry of the Environment 2006: 120). In order to make ecological quality measurable, ecological quality objectives are part of a broader framework in the case of the Barents Sea, and are not as centralized as in the OSPAR framework. Rather, more general environmental objectives are set and defined for pollution, safe seafood, the management of acute pollution, and biological diversity.

The monitoring framework for the Norwegian part of the Barents Sea is first and foremost assembled through selected indicators. These are key aspects that tell something about the marine ecosystem and environment, such as the development trends of a species, water temperature, or the level of pollutants in polar bears. Scientists try to select indicators in such a way that they reflect the complexities of the ecosystem. At the same time, these indicators must remain simple enough to be easily and continuously monitored (Dale and Beyeler 2001). In addition to measuring the status of the ecosystem or environment, the assemblage of indicators must be able to tell something about trends. This is a task that requires communication among scientists, and between scientists and policy-makers, in order to ensure that management can be responsive to changes.

The selection of indicators implies a systematization of nature. In the case of the Barents Sea, the indicators are "stored" in broader categories such as "environmental climate", "commercial fish stocks" or "pollution". The indicators are further specified with the use of parameters, through which they become measurable. In the Barents Sea, this is carried out through a fixation of (1) reference values and (2) threshold levels. Early in the process of establishing the monitoring system there was a focus on the identification of ecological quality objectives for each indicator, but this has received less attention in the later stages.

Reference values relate to the "normal level" of those aspects that are key to ecological or environmental quality. Thus the assemblage of reference values makes up the considered "normal situation" of an ecosystem: its desired condition according to scientists. Consequently, the threshold value is the point at which a change in the measurement data of the indicator is so high that intervention must be considered. It is the maximum level of impact that scientists assume that nature can sustain. Consequently, the assemblage of threshold values makes up the "critical limits" of the ecosystem.

When functioning well, the assemblage of indicators and their parameters are aimed at providing an infrastructure to follow ecological quality, which can be used as an input to policy advice in ecosystem-based management. This presupposes a systematic integration and evaluation of data related to these physical, biological and chemical conditions, as well as a streamlining of the various existing (and to-be-developed) institutional monitoring practices. 
The selection of indicators in the Barents Sea process

In 2003, in line with the preparations towards an integrated, ecosystem-based management plan, the Norwegian Ministry of the Environment commissioned the Institute of Marine Research (IMR) ${ }^{3}$ and the Norwegian Polar Institute (NPI) ${ }^{4}$ to propose a set of indicators for the establishment of an integrated monitoring system (Knol 2010b). The mandate was to identify essential components in the ecosystem; to propose indicators for the health of the ecosystems; and to propose concrete environmental quality objectives for the Barents Sea (von Quillfeldt and Dommasnes 2005). These indicators had to be sensitive enough to detect changes, and at the same time they had to be measureable with sufficient statistical precision in the measurements (ibid: 1). It has been argued that, in general, effective monitoring is only possible when it is underpinned by rigorous statistical design (Lindenmayer and Likens 2009).

How were indicators selected? The ecosystem of the Barents Sea is different from the North Sea for example when it concerns climate, biodiversity, and the effects of pollution. The accessibility of monitoring data and time series is also different. Compared to the preceding practices that had been carried out for the North Sea (under OSPAR), the working group for the Barents Sea found it desirable to incorporate the physical environment to a much larger extent than OSPAR has done for the North Sea. For the North Sea, OSPAR put a relatively large emphasis on eutrophication and on species with a large symbolic value. For the Barents Sea, on the other hand, the working group put more weight on the interrelations of ecosystem components and on the ecosystem's ability to sustainably produce goods and services, which can be harvested or otherwise used (von Quillfeldt and Dommasnes 2005).

The mandate that NPI and IMR received from the Ministry of the Environment in 2003 demanded broad and cross-disciplinary participation. Furthermore, it emphasized the importance of practical connections with public scientific and management bodies such as other governmental directorates. The work was subdivided into four groups, focusing on 1) pollution, 2) fish resources and fisheries, 3) seabirds and marine mammals, 4) bottom fauna and habitats, respectively. In total, around 50 persons participated in the identification of indicators, and in each of the groups a representative from Russia took part. In this first round, 62 indicators were proposed. These 62 indicators were stored into 11 different categories (Table 1). With regard to pollution, 17 specific indicators were proposed, which are presented in Table 2. Four of these 17 pollution indicators were part of established monitoring programs that were functioning well. Data was also available for other indicators, but there was a clear and stated need for more time series and for an adaptation of the monitoring practices. Consequently, either new monitoring practices had to be established for the additional pollution indicators, or existing activities had to be systematically and thoroughly expanded.

This initial phase was concluded in a report prepared by NPI and IMR (von Quillfeldt and Dommasnes 2005). One of the conclusions was that pollution data are unexpectedly weak in relation to how important pollution can be to the ecosystem's function and to the harvesting and marketing of seafood from the Barents Sea (von Quillfeldt and Dommasnes 2005). This explains the desire to expand programs and to get access to more time series. At this stage it was not possible to define, describe or fix the threshold levels of the suggested indicators. There were no threshold levels set for any of the seventeen 
Table 1 Input for the monitoring framework in 2005: categories and number of indicators

\begin{tabular}{ll}
\hline Category & Nr. of indicators \\
\hline Physical environment & 6 \\
Phytoplankton and zooplankton & 5 \\
Ice-edge & 1 \\
Fish and fisheries & 10 \\
Marine mammals & 10 \\
Seabirds & 5 \\
Marine mammals and seabirds (aggregated) & 1 \\
Benthic and habitats & 3 \\
Vulnerable and endangered species & 1 \\
Introduced species & 3 \\
Pollution & 17 \\
Total & $\mathbf{6 2}$ \\
\hline
\end{tabular}

pollution indicators. However, in the report it was written that this would be possible with more available data (von Quillfeldt and Dommasnes 2005).

Furthermore, the scientists described another complication with the monitoring of pollution: the same pollutant can have different effects on different species. In addition to that, new components are discovered regularly, which demands the continuous identification of suitable indicator species (von Quillfeldt and Dommasnes 2005). Monitoring knowledge thus never reaches a final state and transformations in knowledge will require a relatively flexible monitoring system that can include new practices based

Table 2 Existing pollution monitoring practices, and the need for expanded/adapted monitoring practices

\begin{tabular}{|c|c|}
\hline & Existing programs / available data \\
\hline 1 & Pollutants in Norwegian-Arctic cod \\
\hline 2 & Pollutants in Norwegian-Arctic haddock \\
\hline 3 & Pollutants in capelin \\
\hline \multirow[t]{2}{*}{4} & Pollutants in polar cod \\
\hline & Monitoring programs that require adaption \\
\hline 5 & Pollutants in polar bears \\
\hline 6 & Pollutants in ringed seal \\
\hline 7 & Pollutants in bearded seal \\
\hline 8 & Pollutants in walrus \\
\hline 9 & Pollutants in beluga \\
\hline 10 & Pollutants in orca \\
\hline 11 & Pollutants in mink whale \\
\hline 12 & Pollutants in common eider \\
\hline 13 & Pollutants in polar guillemot \\
\hline 14 & Pollutants in herring \\
\hline 15 & Pollutants in shrimp \\
\hline 16 & Pollutants in Iceland scallop \\
\hline 17 & Pollutants in softshell clam \\
\hline
\end{tabular}


on new knowledge. Such an adaptive monitoring framework evolves and develops not only in response to new information, but also in response to new research and management questions that are being posed in relation to the monitoring object or area (Lindenmayer and Likens 2009).

This section has described the early process when NPI and IMR received a mandate from management bodies to propose a set of indicators of ecological quality and change. This was a broad process in which several other institutions with specialized knowledge were invited to take part. The following section describes how the process continued, with a formalization of monitoring tasks and a restructuring of the proposed monitoring framework. In describing the refinement of the monitoring framework, the focus will be on pollution indicators.

\section{Formalizing monitoring tasks and restructuring the framework}

In 2006 the integrated, ecosystem-based management plan for the Barents Sea-Lofoten area was adopted by the Norwegian parliament (Ministry of the Environment 2006). The plan includes a simplified overview of the proposed set of indicators that were presented by the scientists. The former section showed that with the implementation of the management plan considerable parts of this monitoring system were still under development. In order to secure its further development a special group was established that would be responsible for that task. This newly established monitoring group was part of a new structure for the organization and communication of scientific advice for EBM (Knol 2010b), which, in a simplified way, is illustrated in Figure 1.

In addition to the monitoring group, headed by IMR, a forum for environmental risk management was established, which the Coastal Administration coordinates. These two scientific groups report to a "management forum", led by NPI, which subsequently reports the updated scientific work to an interministerial steering committee on a regular basis. This illustration shows the new layer of organizational practices that has been established in the turn towards EBM in Norway.

The mandate of the monitoring group is to coordinate monitoring practices in relation to the management plan, to integrate monitoring results, and to evaluate information in relation to the system with indicators, reference levels and threshold values. A large number of Norwegian expert institutions takes part in the regular meetings of the monitoring group (around 20 different institutions); mainly institutions that already carry out pre-existing monitoring practices in the Barents Sea-Lofoten area, for example

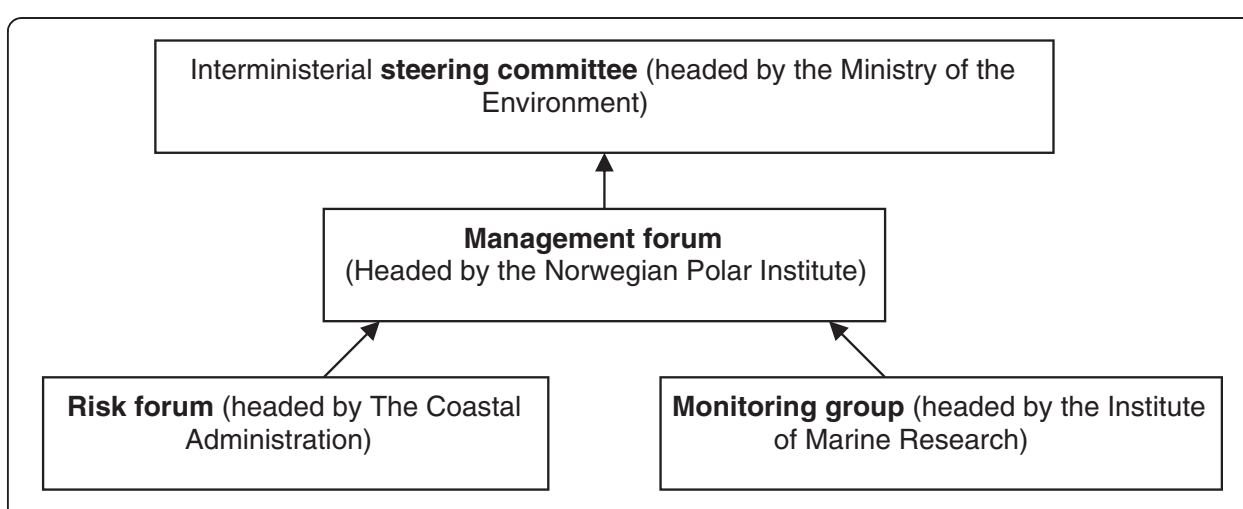

Figure 1 The organization of scientific advice for ecosystem-based management of the Barents Sea. 
the Institute of Marine Research, NIVA (a centre of expertise in water-related issues), the Meteorological Institute, the Norwegian Polar Institute, the Norwegian Radiation Protection Authority, the Norwegian Pollution Control Authority, the Norwegian Biodiversity Information Centre, and the National Institute of Nutrition and Seafood Research. The group received the task to develop the monitoring system further as well as to work towards a method for the integration of monitoring data. The outcomes of the work were presented in a special report of the monitoring group (Sunnanå et al. 2010). The outcomes were also summarized in the 2010 report of the "management forum" (von Quillfeldt 2010). The latter report provided the updated scientific basis for the revision of the integrated management plan, which was presented in the spring of 2011 (Ministry of the Environment 2011).

Before elaborating on the development of pollution indicators, the process so far can be summarized as follows: the first phase of the process started in 2002, when the expert organizations were mandated to propose a set of indicators to measure ecological quality. A selection of indicators was presented in the management plan in 2006. With the implementation of the management plan, a monitoring group was formalized in order to ensure the further development of an integrated monitoring system. This group worked on the redefinition and refinement of indicators. An adapted overall categorization of indicators was made:

1. Physical environment

2. Ice-edge

3. Phytoplankton

4. Zooplankton

5. Non-commercial fish stocks

6. Commercial fish stocks

7. Benthic organisms

8. Seabirds and mammals

9. Introduced species

10.Vulnerable and endangered species

11.Polluting substances

Some indicators were added, while others were left out. Furthermore, the indicators' parameters were further specified. The results of this phase (2006-2010) were presented in a scientific report in 2010 that served as a basis for the revision of the management plan in 2011.

\section{The framework for pollution monitoring}

In the 2010 report, seven pollution categories and a total of 21 pollution indicators were presented (Table 3). For each indicator category, more general objectives were set and descriptions made. Spatial and temporal variability became central elements. The 2010 report emphasizes that indicators must show how pollutant groups and concentrations vary over time (temporal trends), over areas (spatial trends), in different organisms, and in the abiotic environment (e.g. air, sediment). This should provide a basis for the assessment of overall pollution in the marine environment, and for an evaluation of food safety. One of the objectives is to specify the pollution situation in different particularly valuable and 
Table 3 Pollution indicators proposed in 2010

\begin{tabular}{ll}
\hline Sub-category & Indicator \\
\hline Litter in beach areas & Litter in beach areas \\
Supply of components & Atmospheric supply \\
& Supply through rivers \\
Pollutants in sediments & Offshore monitoring related to petroleum activities \\
& Concentrations of hydrocarbons in sediment \\
& Concentration of heavy metals and organochlorine compounds in sediments \\
Pollutants in benthic organisms & Pollutants in mussels \\
& Pollutants in shrimps \\
Pollutants in fish & Pollutants in coastal cod \\
& Pollutants in Atlantic cod \\
& Pollutants in capelin \\
& Pollutants in Arctic cod \\
Pollutants in marine mammals & Pollutants in ringed seal \\
& Pollutants in polar bear \\
& Pollutants in seabirds \\
Radioactivity in sediments & Radioactivity in seaweed \\
Radioactivity & Radioactivity in fish and shrimps \\
Radioactivity in seabirds & Radioactivity in marine mammals \\
\hline &
\end{tabular}

vulnerable areas (Sunnanå et al. 2010), which have been selected in the process towards the integrated management plan (see Knol 2011).

The monitoring of pollution is in line with national and international (EU and OSPAR) regulations. With reference to national regulations, there is a special focus on the prioritized hazardous compounds in White Paper 21 (Ministry of the Environment 2005). It is Norway's national target to eliminate or substantially reduce releases of these priority substances. The polluting substances that are being monitored are, among others, metals, organic toxins, dioxins, and dioxin-like PCBs, as well as radioactivity. In the monitoring framework, the selection of indicator species is related to their status as key species in the ecosystem, or they are species important for the transport of polluting substances in the food chain (Sunnanå et al. 2010).

Compared to the 2005 report, the sub-categories within the category of "pollution" changed somewhat in the work towards the 2010 report (Table 3). Some indicators selected for the 2005 report were removed. Notably, the indicators of the 2005 report that dealt with the level of pollutants in marine mammals were largely cut down in number. Whereas the 2005 report suggested additional monitoring of pollutants in the bearded seal, walrus, beluga, orca and the mink whale (Table 2), the current status of the monitoring framework includes only the ringed seal and the polar bear. Furthermore, the proposed monitoring of pollutants in herring and haddock (proposed in the 2005 report, Table 2) are absent in the 2010 version of the integrated monitoring program. Thus, choices were made that excluded a number of species from the monitoring framework. 
In the 2005 report the working group proposed not to monitor radioactive compounds, cadmium and lead. In addition, the group recommended not to monitor contaminating substances in sediment or in water either (von Quillfeldt and Dommasnes 2005: 115). The 2010 report presented newly selected indicators, including sediment monitoring and radioactivity. Interestingly, these indicators were already part of existing monitoring programs, which were functioning well, and could thus be integrated into the overall monitoring framework. Also from a broader Arctic perspective it is natural to include radioactivity monitoring in the Barents Sea, as radioactivity monitoring is a central part of the Arctic Monitoring and Assessment Programme (AMAP 2011). Accordingly, while some indicators were initially singled out as irrelevant in the context of integrated monitoring, they returned at a later stage as relevant categories. Not only indicators that were already the object of existing monitoring practices were added. "Litter along beach areas" is a new indicator (and simultaneously a new category) for which there exist no time series or monitoring practices, but which was nevertheless added to the integrated monitoring framework.

The 2010 report also demonstrates that it remains difficult to identify the critical limits of the ecosystem in its tolerance of pollution. The threshold values for most pollution indicators were described qualitatively, as follows: "a rise in pollutant concentrations continuing for specified number of years, or a sudden large rise from one sample to the next in an area, to above natural background level" (Sunnanå et al. 2010). Thus, a critical limit is reached when pollutant concentrations rise steadily over years, or when they suddenly rise to above background level. This rather vague definition suggests that the threshold value is at the same level as the indicator's reference value. In other words, the critical limits are already reached when the normal levels are transcended. There is no buffer such as for example in fisheries management in the Northeast Atlantic (Garcia 1994). This lack of a buffer zone between normal level and critical limit could turn out to be problematic, even though critical studies of fisheries management have also pointed at the complexities that arise when such an precautionary approach with buffer zones is used (Hauge et al. 2007; Nielsen 2008).

\section{An instrument starts to take shape}

It has been argued that "given the increasing seriousness of environmental problems throughout the world, there never has been a more important time to establish effective and interacting monitoring programs" (Lindenmayer and Likens 2010: p. 1318). In the planning process for EBM in the Barents Sea-Lofoten area, scientists and policymakers have taken the move towards EBM seriously. Large-scale processes were designed in which actors were mobilized to co-produce a monitoring framework. Through assembling and re-assembling sets of indicators, the contours of a boundary infrastructure for the measurement of ecological quality became visible.

Scientists were asked to provide management bodies with a selection of indicators that are relevant to ecosystem health and functioning. There was, however, little specification of relevant research and governance questions and objectives that relate to ecological quality and change. It has been argued elsewhere that the selection of indicators often does not go along with an explicit statement of what these species or groups are actually indicative of (Lindenmayer and Likens 2010). Many of the involved 
institutions and scientists would argue that the organism they study is special and should be part of a monitoring program. Similarly, one of the scientists in the Barents Sea case argued that they could have described the ecosystem with the use of 3000 indicators (Knol 2010b).

Because explicit objectives lacked in the mandate, the proposed indicators that were presented in the management plan were assembled largely on the basis of pragmatic choices. The indicators that were added later in the process turned out to be the objects of existing monitoring programs (with only a few exceptions). Inevitably, some things remained unclassified, or were "othered" (Bowker 2000): these entities might be equally important, but were overlooked because there are no good funding opportunities. As a result, the politics of nature becomes one of accounting (Asdal 2008), in which some objects are followed, while others are not because there are insufficient resources to take them into account.

The choices that were made during selection processes were mostly guided by preexisting practices, categories and classifications. This shows how EBM further systematizes ecosystems. It is to a very large extent a reordering of existing practices and an attempt to integrate them into a new organizational layer that sits on top of existing institutional practices. The description of the case study also proves that the monitoring framework could have looked different. Other choices could have been made that would have led to a different construction of ecological quality. The assemblage of indicators only presents one of the many possible natures that is specific to the particular time and space in which it was constructed. Nevertheless, one possible outcome of ecological quality was made visible through the assemblage of indicators, which again, was very much determined in size by the available funding opportunities. The next section analyzes the extent to which the monitoring instrument so far has led to a greater potential to control or govern ecological quality.

\section{Limits to control}

The case study provides several insights into the governability and controllability of ecological quality. These relate to the complexity of defining normality as well as to the scientific challenges to monitor over time and across spaces.

Ecological quality refers not only to the assemblage of indicators, but also to the parameters that are given to each of these indicators. EBM can only be made operational through a monitoring system if changes in indicator results lead to responses at the level of governance. For example, when there is a negative trend in the level of pollutants in coastal cod, scientists and policy makers do not necessarily know the causes of these changes and what to do in order to counter such developments. Since many of the pollution indicators do not identify causes (they are classified as "condition-indicator" rather than "effect-indicator") it will remain a large challenge to build strong feedback mechanisms from monitoring results to policy response. As such, an assemblage of indicators is no guarantee for adaptive ecosystem management.

It turned out to be a complex task to specify the reference and threshold values for each indicator; thus to define the normal levels and critical limits of ecological quality. Defining normality implies that questions are asked such as "when does human 
development and its effects transcend the realm of normality?" (Bewers and Wells 1992). Answering such questions clearly surpasses the scientific domain and requires boundary work at the science-policy interface.

Generally, uncertainty and ignorance are central elements in designing frameworks for integrated pollution monitoring. While some uncertainties remain implicit, other uncertainties have been made explicit and can be argued to be forms of non-knowledge. These can be defined as a "type of knowledge where the limits and the borders of knowing are taken into account for future planning and action" (Gross 2007). An example is the ongoing focus in pollution research about the effect that different toxins have on species. With reference to monitoring pollutant substances in polar bears, the monitoring report explains that there is satisfactory knowledge about the negative effects of "old" environmental toxins on the hormone- and immune system of polar bears. There is, however, little knowledge about the aggregated effects of different environmental toxins (Sunnanå et al. 2010). Ongoing research will therefore have consequences for the fixation and adjustment of the indicator's thresholds levels. In other words, ecological and environmental knowledge are always in flux and never reach a final state in which no further effort is demanded. Some would argue that this requires a similarly flexible monitoring approach that can adjust to transformations, additions and changes in knowledge. At the same time, however, the system needs some level of robustness in order to function well, and to be able to provide managers with reliable information. This is a constant challenge in marine and environmental governance.

Apart from such scientific uncertainties and limits to knowing, there are temporal and spatial challenges that pose limits to controlling ecological quality. The 2010 report of the monitoring group makes clear that there is a need for more systematic monitoring practices (Sunnanå et al. 2010). For many of the indictors, it is hard to analyze long-term trends. This is partly due to the existence of brief time series. For other indicators, the difficulty to analyze long-term trends is a consequence of the existence of samples that are taken at irregular intervals. In other words, currently there are temporal shortcomings to existing monitoring data, which makes the overall analysis of trends difficult. There will be practical and financial obstacles to achieve the data that is needed to get sufficient insight into long-term trends.

With the monitoring data that is currently available, spatial differentiation is also only possible to limited degree. Monitoring data is derived from a limited number of sample locations, which complicates practices to develop the monitoring framework into an area-based instrument for EBM, and as a tool in a package for marine spatial planning. It is argued that the monitoring practices need to provide insight into spatial differences in order to assess the relevance for particularly valuable and vulnerable areas (Sunnanå et al. 2010). As a consequence, samples might need to be taken at a larger number of locations. Again, this will be a costly process. In other regions and monitoring studies, the issue of spatial differentiation has led to the question of whether area-based assessments and management requires an adjustment of the indicator's threshold values: if some areas are less sensitive than others, can they also tolerate higher levels of pollution (Bouma 2011)? If that is the case, this calls for an area-based fixation of threshold values and quality objectives for each indicator. The development of specific thresholds in different areas is a costly and highly complicated process and it 
remains to be questioned whether such a system delivers the desired type of policy information.

Other constraints to make ecological quality manageable are of a more institutional nature. Data that supports environmental policy is often complex, ambiguous and dispersed across multiple monitoring networks that are maintained by a variety of organizations (see also Engel-Cox and Hoff 2005; Turnhout and Boonman-Berson 2011). With reference to the Norwegian monitoring framework, Ottersen and colleagues at IMR argue that

"the priorities of each of the monitoring institutions are still tightly connected to the traditional sector-by-sector monitoring. [...] A main obstacle towards the development of interdisciplinary monitoring and reporting on the ecosystems is the simultaneous growth within all sectors of ministry-required demand for sector-specific data and reporting" (Ottersen et al. 2011: 397).

Ecological quality has different meanings in each sector. Consequently, the monitoring framework builds upon a traditional division of labor between the different departments and institutions. This segregation has long been the object of concern among scientists, also with reference in particular to marine pollution (Bewers and Wells 1992; Boelens 1992).

The monitoring group similarly argues that it is a current weakness of its mandate that it does not have any authority to influence the cooperative institutions to implement a specific monitoring activity (Sunnanå et al. 2010: 97). In EBM and environmental governance in general, it is an institutional challenge to coordinate the multiplicity of monitoring institutions and their own programs, strategies, and desires. With the objective to achieve a certain degree of comparison, harmonization and standardization, the establishment of an integrated monitoring framework presupposes the institutional connection of various existing programs, practices, and databases. However, a fully coherent system remains an ideal; it will always be built on concessions about the quality of data (see also Bowker and Star 1999).

\section{Conclusion}

This paper has offered a way to study ecosystem-based management in practice. The principles and objectives of ecosystem-based management are often formulated in general terms, reflecting ideal situations, without giving a clear idea of what "ecological quality" implies in a specific context. It is therefore more insightful to study the ways in which ecosystem-based management is made operational through a focus on the co-production of its instruments. The study has thereby provided inroads into understanding the constructed nature of ecological quality.

Monitoring is considered to be a central part of the instrumentation of ecosystembased management. The main contours of the monitoring instrument studied in this paper take shape through an assemblage of indicators and their parameters that tell us something about ecological quality. It is, however, no straightforward task for scientists to determine the normal levels and critical limits of ecological quality. This process requires thorough communication and negotiation at the boundary of science and politics. 
A solid monitoring framework does not necessarily equate to governability. The Barents Sea case study has highlighted the limits to the controllability of ecological quality. One of the most popular ways to increase governability is by attempting to reduce scientific uncertainty. But as there will never be complete knowledge for marine governance, these instruments of marine governance will never cease to be in the making.

This paper also discussed the enduring limits to control that are of a more practical and institutional nature. There are, and will always be, spatial and temporal constraints to data that pose restrictions to following and controlling ecological quality. This paper provided insight into the ways in which pragmatic choices, guided by financial limitations, lead the way towards implementing ecosystem-based management.

There is no panacea for ecological monitoring, just as there is no one-size-fits-all solution for ecosystem-based management. Each country or region that introduces plans for ecosystem-based management builds upon its own pre-existing practices, rules, roles and procedures. The institutional challenge of coordinating the large variety of monitoring institutions and their own programs and practices asks for different responses in each country or region. It will however remain relevant to follow the co-production of the monitoring framework for the Barents Sea further in time, as it does provide a relevant example of how scientists and policy-makers deal with limits to control when implementing integrated forms of ecosystem-based management.

\section{Endnotes}

${ }^{1}$ ICES, which was established in 1902, coordinates marine research in the North Atlantic. Members of the ICES community include all coastal states bordering the North Atlantic and the Baltic Sea. ICES cooperates with organizations and institutes on an international scale. www.ices.dk.

${ }^{2}$ OSPAR is an international cooperation platform for the protection of the marine environment in the North-East Atlantic, in which 15 governments participate. It started in 1972 with the Oslo Convention against dumping.

${ }^{3}$ IMR is a scientific institution that is linked to the Ministry of Fisheries and Coastal Affairs and receives about $50 \%$ of its funding from the ministry. Most of the scientific advice for fisheries management in Norway comes from IMR.

${ }^{4} \mathrm{NPI}$ is a directorate under the Ministry of the Environment and is active in the monitoring of climate, environmental pollutants and biodiversity. Furthermore, among NPI's key activities are geological and topographic mapping.

Competing interests

The author declares that there are no competing interests.

Acknowledgements

This research was funded through the demosreg program of the Norwegian Research Council. I am grateful to Peter Arbo, Bjørn Hersoug, Glen Smith and two anonymous reviewers for their constructive comments on earlier versions of this paper.

Received: 29 June 2012 Accepted: 23 January 2013 Published: 22 May 2013 


\section{References}

AMAP. 2011. Arctic Pollution. Oslo: Arctic Monitoring and Assessment Programme (AMAP).

Asdal, K. 2003. The problematic nature of nature: The post-constructivist challenge to environmental history. History and Theory 42(4): 60-74.

Asdal, K. 2008. Enacting things through numbers: Taking nature into account/ing. Geoforum 39(1): 123-132.

Bewers, J.M., and P.G. Wells. 1992. Challenges for improved marine environmental protection. Mar Pollut Bull 25(1-4): 112-117.

Boelens, R.G.V. 1992. From policies to science: Strategies for marine environmental protection. Mar Pollut Bull 25(1-4): 14-17.

Bouma, J. 2011. Applying indicators, threshold values and proxies in environmental legislation: A case study for Dutch dairy farming. Environmental Science \& Policy 14(3): 231-238.

Bowker, G.C. 2000. Biodiversity Datadiversity. Soc Stud Sci 30(5): 643-683.

Bowker, G.C., and S.L. Star. 1999. Sorting things out: classification and its consequences. Cambridge, Mass: MIT Press.

Browman, H.I., and K.I. Stergiou. 2004. Perspectives on ecosystem-based approaches to the management of marine resources. Mar Ecol Prog Ser 274: 269-303.

Clarke, A.E., and S.L. Star. 2008. The social worlds framework: a theory/methods package. In The Handbook of Science and Technology Studies, ed. E.J. Hackett, O. Amsterdamska, M. Lynch, and J. Wajcman, 113-138. Cambridge, Massachusetts: The MIT Press.

Crowder, L., and E. Norse. 2008. Essential ecological insights for ecosystem-based management and marine spatial planning. Marine Policy 32(5): 772-778.

Curtin, R., and R. Prellezo. 2010. Understanding marine ecosystem based management: A literature review. Marine Policy 34(5): 821-830

Dale, V.H., and S.C. Beyeler. 2001. Challenges in the development and use of ecological indicators. Ecol Indic 1(1): 3-10.

Day, J. 2008. The need and practice of monitoring, evaluating and adapting marine planning and management lessons from the Great Barrier Reef. Marine Policy 32(5): 823-831.

Day, V., R. Paxinos, J. Emmett, A. Wright, and M. Goecker. 2008. The marine planning framework for South Australia: a new ecosystem-based zoning policy for marine management. Marine Policy 32: 535-543.

Douvere, F., and C. Ehler. 2011. The importance of monitoring and evaluation in adaptive maritime spatial planning $J$ Coast Conserv 15(2): 305-311.

Ducrotoy, J.P., and M. Elliott. 1997. Interrelations between science and policy-making: the North Sea example. Mar Pollut Bull 34(9): 686-701.

Engel-Cox, J.A., and R.M. Hoff. 2005. Science-policy data compact: use of environmental monitoring data for air quality policy. Environmental Science and Policy 8(2): 115-131.

Gaichas, S.K. 2008. A context for ecosystem-based fishery management: developing concepts of ecosystems and sustainability. Marine Policy 32(3): 393-401.

Garcia, S. 1994. The precautionary approach to fisheries with reference to straddling fish stocks and highly migratory fish stocks. Roma: Food and Agriculture Organization of the United Nations, FAO.

Gross, M. 2007. The Unknown in Process: Dynamic Connections of Ignorance, Non-Knowledge and Related Concepts. Curr Sociol 55: 742-759.

Hauge, K.H., K.N. Nielsen, and K. Korsbrekke. 2007. Limits to transparency-exploring conceptual and operational aspects of the ICES framework for providing precautionary fisheries management advice. ICES J Mar Sci 64: 738-734.

Jasanoff, S. 2004. States of knowledge: the co-production of science and social order. London: Routledge.

Kassim, H., and P. Le Galès. 2010. Exploring Governance in a Multi-Level Polity: A Policy Instruments Approach. West European Politics 33(1): 1-21.

Katsanevakis, S., V. Stelzenmüller, A. South, T.K. Sorensen, P.J.S. Jones, S. Kerr, F. Badalamenti, C. Anagnostou, P. Breen, G. Chust, G. D'Anna, M. Duijn, T. Filatova, F. Fiorentino, H. Hulsman, K. Johnson, A.P. Karageorgis, I. Kröncke, S. Mirto, C. Pipitone, S. Portelli, W. Qiu, H. Reiss, D. Sakellariou, M. Salomidi, L. Van Hoof, V. Vassilopoulou, T. Vega Fernández, A. Vöge, A. Weber, A. Zenetos, and R.T. Hofstede. 2011. Ecosystem-based marine spatial management: Review of concepts, policies, tools, and critical issues. Ocean \& Coastal Management 11: 807-820.

Knol, M. 2010a. Marine ecosystem governance in the making: Planning for petroleum activity in the Barents Sea-Lofoten area. Tromsø: PhD Thesis, University of Troms $\varnothing$.

Knol, M. 2010b. Scientific advice in integrated ocean management: the process towards the Barents Sea plan. Marine Policy 34(2): 252-260

Knol, M. 2011. Mapping ocean governance: from ecological values to policy instrumentation. J Environ Plan Manag 54(7): 979-995.

Lascoumes, P., and P. Le Galès. 2007. Introduction: understanding public policy through its instruments: from the nature of instruments to the sociology of public policy instrumentation. Governance: an International Journal of Policy, Administration, and Institutions 20(1): 1-21.

Latour, B. 2004. Politics of nature: how to bring the sciences into democracy. Cambridge, Mass: Harvard University Press.

Levin, S. 1998. Ecosystems and the biosphere as complex adaptive systems. Ecosystems 1: 431-436.

Lindenmayer, D.B., and G.E. Likens. 2009. Adaptive monitoring: a new paradigm for long-term research and monitoring. Trends in Ecology and Evolution 24(9): 482-486.

Lindenmayer, D.B., and G.E. Likens. 2010. The science and application of ecological monitoring. Biol Conserv 143(6): $1317-1328$.

McIntyre, A.D. 1995. Environmental monitoring of the oceans. Marine Policy 19(6): 497-502.

Ministry of the Environment. Oslo: 2005. White Paper No. 21 (2004-2005): The Government's Environmental Policy and the State of the Environment.

Ministry of the Environment, 2006. White Paper No. 8 (2005-2006): Integrated Management of the Marine Environment of the Barents Sea and the Sea Areas off the Lofoten Islands. Oslo.

Ministry of the Environment. Oslo: 2011. White Paper No. 10 (2010-2011): Update of the management plan for the marine environment of the Barents Sea-Lofoten area (in Norwegian). 
Nielsen, K.N. 2008. Science|Politics: Boundary construction in mandated science - The case of ICES' advice on fisheries management. Tromsø: PhD thesis, University of Troms $\varnothing$.

Österblom, H., A. Gårdmark, L. Bergström, B. Müller-Karulis, C. Folke, M. Lindegren, M. Casini, P. Olsson, R. Diekmann, T. Blenckner, C. Humborg, and C. Möllmann. 2010. Making the ecosystem approach operational—Can regime shifts in ecological- and governance systems facilitate the transition? Marine Policy 34(6): 1290-1299.

Ottersen, G. E. Olsen, G.I. van der Meeren, A. Dommasnes, and H. Loeng. 2011. The Norwegian plan for integrated ecosystem-based management of the marine environment in the Norwegian Sea. Marine Policy 35(3): 389-398.

Rouse, J. 1987. Knowledge and Power. Toward a Political Philosophy of Science. Ithaca/London: Cornell University Press.

Sunnanå, K., M. Fossheim, and C.D. Olseng. 2010. Forvaltningsplan Barentshavet - rapport fra overvakingsgruppen 2010. Bergen: Fisken og havet Bergen, Institute of Marine Research.

Turnhout, E., and S. Boonman-Berson. 2011. Databases, Scaling Practices, and the Globalization of Biodiversity. Ecol Soc 16(1): 35. van Tatenhove, J. 2011. Integrated marine governance: Questions of legitimacy. Maritime Studies 10(1): 87-113.

von Quillfeldt, C.H. Institute of Marine Research. Bergen: 2010. Det faglige grunnlaget for oppdateringen av forvaltningsplanen for Barentshavet og havområdene utenfor Lofoten. Fisken og havet. saernummer 1a-2010.

von Quillfeldt, C.H., and A. Dommasnes. 2005. Forslag til indikatorer og miljøkvalitetsmål for Barentshavet: Rapport fra et delprosjekt under forvaltningsplanen for Barentshavet. Norway: Norwegian Polar Institute \& Institute of Marine Research.

Wehling, P. 2006. The situated materiality of scientific practices: postconstructivism - a new theoretical perspective in science studies? Science, Technology and Innovation Studies Special Issue 1: 81-100.

doi:10.1186/2212-9790-12-5

Cite this article as: Knol: Making ecosystem-based management operational: integrated monitoring in Norway.

Maritime Studies 2013 12:5.

\section{Submit your manuscript to a SpringerOpen ${ }^{\circ}$ journal and benefit from:}

- Convenient online submission

- Rigorous peer review

- Immediate publication on acceptance

- Open access: articles freely available online

- High visibility within the field

- Retaining the copyright to your article

Submit your next manuscript at $\gg$ springeropen.com 